\title{
Anthracyclin - Based Chemotherapy in Patients with Non-Hodgkin Lymphoma Aged Over 75
}

\author{
Furkan SARICI, Neyran KERTMEN, AIma C. ASLAN, Vildan TASDEMIR, Taner BABACAN, \\ Saadettin KILICKAP, Evren OZDEMIR, Ibrahim BARISTA, Alev TURKER, Ayse KARS
}

Hacettepe University Faculty of Medicine, Department of Medical Oncology, Ankara, TURKEY

\begin{abstract}
The optimal treatment of non-Hodgkin lymphoma (NHL) in elderly patients is controversial. In this study, we evaluated the outcomes for elderly patients who were treated with combined chemotherapy regimens. Patients with lymphoma aged over 75 treated at our Cancer Institute between 2005 and 2014 were evaluated retrospectively. Demographic data were collected from 76 elderly lymphoma cases receiving Rituximab-Chemotherapy, Chemotherapy only or Rituximab only. Survival or death during treatment were recorded, and lengths of progression-free survival (PFS) and overall survival (OS) were calculated. Seventy-six elderly patients with lymphoma were enrolled, $51.4 \%(n=39)$ male and $48.6 \%(n=37)$ female. Median age at diagnosis was $79(75-95)$ years. Histopathological examination revealed diffuse large B cell lymphoma (DLBCL) in 52\% ( $n=40)$ of patients, follicular lymphoma in $21 \%(n=16)$, marginal zone lymphoma in 10.5\% ( $n=8)$, mantle cell lymphoma in $5.3 \%(n=4)$, and T cell lymphoma in 9.2\% ( $n=7)$. Median PFS and median OS were 50.1 and 45.9 months, respectively. In this trial, PFS and OS levels in the high grade lymphoma were not significantly different from those in the low and intermediate grade groups ( $p=0.16$ and $p=0.49$ respectively). Comorbidity did not have a significant effect on PFS or OS ( $p=0.71$ and $p=0.93$ ). In conclusion, anthracyclin-based chemotherapy regimens are not significantly better than the others in terms of PFS ( $p=0.32)$ and OS $(p=0.8)$. Survival outcomes of anthracyclin-based chemotherapy regimens in elderly lymphoma patients are similar to those of non-anthracycline-based chemotherapy regimens.
\end{abstract}

Keywords: Elderly patients, Lymphoma treatment, Anthracyclin

\section{ÖZET}

\section{Yetmişbeş Yaş ve Üzeri Non-Hdgkin Lenfoma Hastalarında Antrasiklin Bazlı Kemoterapiler}

Yaşı hastalarda Non-Hodgkin lenfomanın (NHL) optimal tedavisi tartışmalıdır. Bu çalışmada kombine kemoterapiler uygulanan yaşı NHL hastalarının tedavi sonuçları değerlendirildi. Kanser enstitümüzde 2005 ile 2014 yılları arasında tedavi edilen 75 yaş ve üstü lenfoma hastalarının retrospektif olarak değerlendirmesi yapıldı. Rituksimab-kemoterapi, sadece kemoterapi ve sadece Rituksimab alan 76 yașıı lenfoma hastasının demografik verileri elde edildi. Tedavi sırasında sağkalım ve ölümler kaydedildi. Progresyonsuz sağkalım (PS) ve genel sağkalım (GS) süreleri hesaplandı. Toplam 76 lenfoma hastası kaydedildi. Hastaların \%51.4'ü ( $n=39$ ) erkek, \%48.6' sı ( $n=37)$ kadındı. Tanı anında ortanca yaș 79'du (75-95). Histopatolojik olarak hastaların \%52' si $(n=40)$ diffüz büyük B hücreli lenfoma (DBBHL) iken, \%21'i $(n=16)$ folliküler lenfoma, \%10.5' i $(n=8)$ marjinal zon lenfoma, \%5.3 ( $n=4)$ mantle hücreli lenfoma ve \%9.2'si $(n=$ 7) T-hücreli lenfoma histolojisine sahipti. Ortanca PS ve GS sırasıyla 50.1 ve 45.9 aydı. Yüksek dereceli lenfomaların PS ve GS değerleri, düşük ve orta dereceli gruplar ile karşılaştııılığında anlamlı farkllık görülmedi (Sırasıyla $p=0.16$ ve $p=0.49$ ). Komorbitelerin PS ve GS üzerinde anlamlı etkisi yoktu ( $p=0.71$ ve $p=0.93$ ). Sonuç olarak, antrasiklin bazlı kemoterapi rejimlerinin antrasiklin içermeyen rejimlere kıyasla anlamlı PS ( $p=0.32)$ ve GS ( $p=0.8)$ üstünlüğü yoktu. Yaşıı lenfoma hastalarında antrasiklin bazlı kemoterapi rejimleri ile antrasiklin içermeyen rejimlerinin sağkalım sonuçları benzerdi.

Anahtar Kelimeler: Yaşlı hasta, Lenfoma tedavisi, Antrasiklin 


\section{INTRODUCTION}

The incidence rate of non-Hodgkin lymphoma (NHL) increases with advanced age and one-third of cases occur in patients $\geq 70$ years of age. ${ }^{1}$ Age is one of the most important prognostic factor. ${ }^{2} \mathrm{In}$ eldery patients with diffuse large B-cell subtype, overall survival decreases with age., ${ }^{2,3}$

The most effective management strategies and chemotherapy regimens for elderly patients have still controversial. Although NHL can be effectively treated with aggressive combined chemotherapy regimens, advanced age may be an obstacle for aggressive treatment. Decreased hematological reserve, reduced performance status, decreased drug metabolism, and comorbid diseases such as decreased left ventricle ejection fraction, hepatic or renal impairment may affect to choose treatment regimen in elderly patients.

Anthracycline is one of the cornerstones of therapy for lymphoma and is used as combine with other chemotherapy drugs. Higher response rate and improved overall survival were achieved in elderly patients with diffuse large B-cell lymphoma who were treated with anthracycline-containing chemotherapy regimens compared to those who received non-anthracycline chemotherapy regimens. ${ }^{4}$ However, cardiac toxicity is the most important lifetreating adverse effect of anthracycline. The risk of cardiotoxicity of anthracyclines may limit the use in elderly patients.

In this study, we aimed to evaluate efficacy of anthracycline and non-anthracycline-containg regimens in $\geq 75$ years patients with NHL.

\section{PATIENTS AND METHODS}

In this study we retrospectively evaluated the treatment options and their results in elderly patients with non-Hodgkin lymphoma who were treated at the Hacettepe University Faculty of Medicine, Turkey, between 2005 and 2014. Demographic data were collected from 76 elderly lymphoma cases with older than 75 years (age, sex, comorbidity, Aestern Cooperative Oncology Group (ECOG) performance status, stage, presence of B symptoms, serum lactat dehydrogenase (LDH) levels, presence of extranodal disease and bone marrow involvement. Also, histological subtype of lym- phoma, used with treatment regimens and response to treatment were recorded.

Response to chemotherapy was evaluated after 3 cycles, or following discontinuation of the planned treatment. Thereafter, clinical examination was performed every 3 months for the first 2 years, and then every 6 months for 3 years. A neck, chest, and abdominal computed tomographic scan were performed after 6 months, and then every 6 months during the first 5 years. After 5 years, clinical examination was performed once a year.

Complete remission (CR) was defined as disappearance of all target lesions and a decrease in the short axis measurement of all pathological lymph nodes to $\leq 10 \mathrm{~mm}$. Partial response (PR) was defined as a $30 \%$ decrease in measurable tumor mass after treatment, with no new areas of tumor development and no tumor area exhibiting progression. Progression (PD) was defined as $\mathrm{a} \geq 20 \%$ increase of at least $5 \mathrm{~mm}$ in the sum of the longest diameters of the target lesions compared with the smallest sum of the longest diameter recorded or the appearance of new lesions including those detected by fludeoxyglucose-positron emission tomography (FDG-PET). Stable disease was defined as measurable tumor not meeting the criteria for either PR or PD (RECIST guideline, version 1.1).

\section{Statistical Analysis}

Data were analyzed using the Statistical Package for the Social Sciences (SPSS) version 15.0. Statistical analyses were two-way, and $\mathrm{p}<0.05$ was considered statistically significant. Chi-square test was used to demonstrate differences between nominal and ordinal variables. Mann-Whitney $U$ test and Wilcoxon test were used to analyse differences between independent variables, and Student's- $t$ test was used to evaluate numerical variables with normal distribution. Overall and progression-free survivals were analyzed by the Kaplan-Meier.

\section{RESULTS}

Seventy-six elderly lymphoma patients were included in the study. At the time of diagnosis, the median age was 79 years (75-95). Mean follow-up period was 29 months. Patients' demographic data are given in Table 1 and Table 2. 


\begin{tabular}{|c|c|c|}
\hline & n (76) & $\%$ \\
\hline \multicolumn{3}{|l|}{ Age (median [min - max] 79 (75-95) } \\
\hline BMI (median) & 27 & \\
\hline \multicolumn{3}{|l|}{ Sex } \\
\hline Male & 39 & 51.4 \\
\hline Female & 37 & 48.6 \\
\hline \multicolumn{3}{|l|}{ Comorbidity } \\
\hline No & 18 & 23.7 \\
\hline 1 & 22 & 28.9 \\
\hline$>1$ & 36 & 47.4 \\
\hline \multicolumn{3}{|l|}{ Stage } \\
\hline I & 11 & 14.5 \\
\hline$\|$ & 11 & 14.5 \\
\hline III & 33 & 43.3 \\
\hline IV & 21 & 27.6 \\
\hline \multicolumn{3}{|l|}{ B-Symptoms } \\
\hline Yes & 34 & 44.8 \\
\hline No & 42 & 55.2 \\
\hline \multicolumn{3}{|l|}{ ECOG (performance status) } \\
\hline $0-1$ & 44 & 52.0 \\
\hline$\|$ & 27 & 35.5 \\
\hline III & 4 & 5.3 \\
\hline IV & 1 & 1.3 \\
\hline \multicolumn{3}{|l|}{ Histopathologic subgroups } \\
\hline DLBCL & 40 & 52.0 \\
\hline Folliculer lymphoma & 16 & 21.0 \\
\hline Mantle cell lymphoma & 4 & 5.3 \\
\hline Marginale zone lymphoma & 8 & 10.5 \\
\hline T cell lymphoma & 7 & 9.2 \\
\hline Non-classified low grade NHL & & 1.3 \\
\hline \multicolumn{3}{|c|}{$\begin{array}{l}\text { BMI: Body mass index; ECOG: Eastern Cooperative Oncology Group; } \\
\text { DLBLC: Difuse large B cell lymphoma }\end{array}$} \\
\hline
\end{tabular}

Extranodal involvement mostly spleen and bone narrow was observed in $51 \%(\mathrm{n}=39)$ of our patients (Bone marrow involvement in $18.4 \%$, $\mathrm{n}=$

\begin{tabular}{|lll|}
\hline Table 2. Comorbidity of the patients & \\
\hline & $\mathbf{n}$ & $\%$ \\
\hline Hypertension & 32 & 42 \\
Diabetes mellitus & 17 & 22 \\
Coronary artery disease & 12 & 15 \\
Cardiac failure & 7 & 9 \\
Osteoporosis & 9 & 11 \\
Chronic obstructive & 4 & 5 \\
pulmonary disease & & \\
Hypothyroidism & 4 & 5 \\
Depression & 4 & 5 \\
Demans & 3 & 3 \\
Parkinson disease & 2 & 2 \\
Rheumatoid arthritis & 2 & 2 \\
Primary biliary cirrhosis & 1 & 1 \\
\hline
\end{tabular}

14). Serum $\beta 2$ - microglobulin levels were elevated in $44 \%$ and $\mathrm{LDH}$ levels in $91 \%$ of the patients. Treatment modalities are shown in Table 3.

\section{Tumor Characteristics and Treatment Modalities}

Histopathological examination revealed diffuse large B cell lymphoma (DLBCL) in 52\% $(n=40)$ of patients, follicular lymphoma in $21 \%(n=16)$, mantle cell lymphoma in $5.3 \%(n=4)$, marginale zone lymphoma in $10.5 \%(\mathrm{n}=8)$, T cell lymphoma in $9.2 \%(n=7)$ and $1.3 \%(n=1)$ non-classified low grade NHL. Patients were generally diagnosed with advanced stage disease. Stage III disease was recorded in $35 \%$ of DLBCL patients and $27 \%$ of follicular lymphoma patients.

Forty-five percent $(n=17)$ of DLBCL patients and $75 \%(n=3)$ of mantle cell lymphoma patients received rituximab-cyclophosphamide, doxorubicin, vincristine and prednisone (R-CHOP) therapy. T cell lymphoma patients mostly received $\mathrm{CHOP}$ therapy. Eighty-seven percent $(n=14)$ of follicular lymphoma patients received regimens such as rituximab (R), rituximab-cyclophosphamide (RC) and rituximab-cyclophosphamide, vincristine, 


\begin{tabular}{|c|c|c|}
\hline & n (76) & $\%$ \\
\hline \multicolumn{3}{|l|}{ Radiotherapy } \\
\hline Yes & 21 & 27 \\
\hline No & 55 & 72 \\
\hline \multicolumn{3}{|l|}{ Chemotherapy } \\
\hline Rituximab only & 4 & 5 \\
\hline $\mathrm{R}-\mathrm{CHOP}$ & 26 & 34 \\
\hline R-CVP & 9 & 11 \\
\hline R-CNOP & 11 & 14 \\
\hline $\mathrm{R}-\mathrm{C}$ & 8 & 10 \\
\hline R-bendamustin & 2 & 2 \\
\hline $\mathrm{CHOP}$ & 4 & 5 \\
\hline The others & 4 & 5 \\
\hline No treatment & 8 & 10 \\
\hline \multicolumn{3}{|c|}{$\begin{array}{l}\text { R-CHOP: Rituximab-cyclophosphamide, doxorubicin, vincristine, } \\
\text { prednisone; R-CVP: Rituximab-cyclophosphamide, vincristine, pred- } \\
\text { nisone; R-CNOP: Rituximab-cyclophosphamide, mitoxantrone, vin- } \\
\text { cristine, prednisone; R-C: Rituximab-cyclophosphamide; CHOP: Cy- } \\
\text { clophosphamide, doxorubicin, vincristine, prednisone; } \\
\text { The others: CNOP, R-CP, CVP }\end{array}$} \\
\hline
\end{tabular}

prednisone (R-CVP). The majority, 71\%, of marginal zone lymphoma patients received non-adriamycin-based therapies.

\section{Survival}

The median progression free survival (PFS) was 50.1 months. No difference in PFS was determined between aggressive and indolent lymphomas $(\mathrm{p}=$ 0.16 ). No difference in PFS was also detected between male and female genders $(p=0.80)$.

Analysis of the effect of the patients' characteristics on PFS revealed no difference in ECOG in terms of time of diagnosis $(\mathrm{p}=0.15)$, stage $(\mathrm{p}=0.98)$, presence of $B$ symptoms $(p=0.57)$, bone marrow involvement $(\mathrm{p}=0.87)$, extranodal disease $(\mathrm{p}=$ $0.85)$, presence of anemia $(p=0.20)$, presence of lymphopenia $(\mathrm{p}=0.42)$, elevated B2 microglobulin $(p=0.24)$ or sedimentation $(p=0.28)$. Comorbidity $(\mathrm{p}=0.71)$ and comorbidity requiring treatment $(p=0.27)$ had no effect on PFS. Investigation of

\begin{tabular}{|c|c|c|c|}
\hline Parameters & $\begin{array}{l}\text { Antra- } \\
\text { cycline }\end{array}$ & $\begin{array}{l}\text { Non-antra } \\
\text { cycline }\end{array}$ & $P$ value \\
\hline \multicolumn{4}{|l|}{ Indolent NHL } \\
\hline PFS (months) & 50.2 & 38.3 & 0.46 \\
\hline OS (months) & 66.2 & 46.9 & 0.27 \\
\hline \multicolumn{4}{|l|}{ Aggresive NHL } \\
\hline PFS (months) & 49.6 & 34.0 & 0.33 \\
\hline OS (months) & 61.7 & 42.8 & 0.40 \\
\hline \multicolumn{4}{|l|}{ Overall } \\
\hline PFS (months) & 49.8 & 36.6 & 0.67 \\
\hline OS (months) & 65.1 & 43.2 & 0.80 \\
\hline OS: Overall survival & & & \\
\hline
\end{tabular}

the effect of chemotherapy on PFS revealed that receipt of adriamycin-based or non-adriamycinbased therapy had no effect on PFS ( $\mathrm{p}=0.32)$. Radiotherapy also had no effect on PFS ( $p=0.29$ ).

The median OS was 45.9 months. No difference in OS was determined between aggressive and indolent lymphomas (p: 0.49). Examination of patient characteristics revealed no significant effect on OS of stage of disease $(\mathrm{p}=0.14)$, presence of $\mathrm{B}$ symptom $(p=0.14)$, extranodal disease $(p=0.71)$, presence of lymphopenia ( $\mathrm{p}=0.40), \mathrm{B} 2$ microglobulin elevation $(p=0.39)$, sedimentation $(p=0.30)$ or gender $(\mathrm{p}=0.39)$. Examination of comorbidity $(\mathrm{p}=0.93)$ and comorbidity requiring treatment $(\mathrm{p}=$ 0.96 ) also identified no effect on OS. ECOG performance status $(p=0.01)$, bone marrow involvement $(p=0.02)$ and presence of anemia at the baseline $(p=0.01)$ had a significant effect on OS.

Investigation of the effect of chemotherapy on OS revealed that anthracyclin-based chemotherapy had no effect on OS $(p=0.80)$. Mean survival of patients receiving anthracyclin-based therapy was 65 months, compared to 43 months in those receiving nonanthracyclin-based therapy $(\mathrm{p}=0.80)$. Radiotherapy had no effect on OS $(p=0.45)$. The survival data are shown in Table 4. 


\section{DISCUSSION}

At diagnosis, most of our patients had good performance status, comorbidity (one or more), B symptoms had a high LDH level (91\%), mostly extranodal disease and many were in an advanced stage. Serum B2 microgloblun levels were elevated in $44 \%$ of the patients. Median age at the diagnosis was 79 years $(75-95)$.

The standart treatment of non-Hodgkin lymphoma (NHL) in elderly patients is still controversial. Age is known to be an adverse prognostic factor in all subtypes of NHL. ${ }^{5}$ At advanced age, other factors (e.g., comorbidity and functional status), in addition to age and PS may play an important role in determining the survival of NHL patients. ${ }^{6}$ Clinical studies in elderly NHL patients have shown the negative impact of comorbidity on prognosis. ${ }^{7-12}$ There has been little investigation of the relevance of functional status and/or comorbidity in elderly patients with NHL. ECOG performance status was $0-1$ in $57.8 \%(n=44)$ of our study group. When ECOG was compared, a difference was observed on OS (p: 0.01). A difference on OS was also determined in the presence of anemia, which significantly affects performance status $(\mathrm{p}=0.01)$. In addition, no effect was determined on PFS or OS in patients with comorbidity or comorbidity requiring treatment $(\mathrm{p}=0.71$ and $\mathrm{p}=0.27)(\mathrm{p}=0.93$ and $\mathrm{p}=$ 0.96).

Three large phase III, randomized, prospective clinical trials and a large population registry in the Netherlands have shown that DLBCL is significantly more frequent among elderly patients, in contrast to follicular lymphoma. ${ }^{3,5,13,14}$ DLBCL comprised the majority of the cases in our study group (50\% patients, $n=40)$ too.

Patients with disseminated high-grade extranodal NHL have been shown to exhibit the poorest prognosis. ${ }^{15}$ Extranodal involvement mostly spleen and bone narrow were observed in $50 \%(n=39)$ of our patients( Bone marrow involvement in $18.4 \%, \mathrm{n}=$ 14). Moreover, in Carbone et al.'s study, 52\% of NHL cases were extranodal at presentation, and the gastrointestinal tract was the most frequently involved site (47.3\%). ${ }^{16}$ D'Amore et al. reported that extranodal presentation, particularly involving the stomach and bone marrow. ${ }^{17}$ Finally, extranodal disease was determined in approximately $40 \%$ of patients with NHL aged over 80 in two institutions. ${ }^{18}$

In our study median length of follow-up was 29 months. Median PFS was 50.1 months and median OS 45.9 months. No difference was determined in PFS $(\mathrm{p}=0.16)$ or OS $(\mathrm{p}=0.49)$ between aggressive and indolent lymphomas $(\mathrm{p}=0.49)$. Opposite to this, Bairey $\mathrm{O}$ et all revealed that patients with indolent lymphomas had a significantly better 3-year survival and median survival than those with aggressive lymphomas. ${ }^{1}$

The most appropriate treatment for elderly patients with lymphoma is the subject of debate. Standard regimens may not be possible for reasons such as comorbidity, performance status, using other drugs and social support. In our study $45 \%(n=$ 17) of DLBCL patients and $75 \%(n=3)$ of mantle cell lymphoma patients received R-CHOP and $\mathrm{T}$ cell lymphoma patients mostly received $\mathrm{CHOP}$ therapy. Eighty-seven percent $(n=14)$ of follicular lymphoma patients received regimens such as $\mathrm{R}$, $\mathrm{R}-\mathrm{C}$ and R-CVP. The majority, $71 \%$, of marginal zone lymphoma patients received non-adriamycin-based therapies. Investigation of the effect of chemotherapy on PFS revealed that receipt of anthracyclin-based or non-anthracyclin-based therapy had no effect on PFS $(p=0.32)$. Also investigation of the effect of chemotherapy on OS revealed that anthracyclin-based theraphy had no effect on OS $(p=0.80)$. Mean survival of patients receiving anthracyclin-based therapy was 65 months, compared to 43 months in those receiving nonanthracyclin-based therapy $(\mathrm{p}=0.80)$. Radiotherapy had no effect on PFS and OS ( $p=0.29, p=0.45)$.

In a study from 2001, Tirelli $U$ et al. described the $\mathrm{CHOP}$ regimen as the standard therapy in patients with stage II-III lymphoma aged 70 or above. ${ }^{19}$ In another retrospective study, Grogan $\mathrm{L}$ et al. the patients received similar regimens with the same chemotherapy dose intensity, irrespective of age. ${ }^{20}$ Standard-dose m-BACOD (methotrexate, bleomycin, adriamycin, cyclophosphamide, vincristine and prednisone) or CHOP were used to treat elderly patients and patients $<65$. The 3-year OS and 3 -year PFS of patients $>65$ years $(58 \%)$ were not significantly different from those of patients $<65$ years $(65 \%)$ treated with the same regimen. 
Randomized phase III clinical studies have compared the CHOP and CNOP regimens in elderly lymphoma patients and reported significantly better OS and disease-free survival in patients treated with CHOP than in those receiving CNOP. ${ }^{21,22}$ In contrast to those results, analysis of the effect on survival of chemotherapy regimens that adriamycin-based or not had no effect on PFS ( $p=0.32)$ and OS $(\mathrm{p}=0.80)$ in our study. Also in Davis CC et all. study there was no statistically significance in PFS or OS for patients who received adriamycin containing chemotheraphy and those who did not. Interestingly, tolerability was similar between the two treatment groups. ${ }^{23}$

This may be attributed to the varying grades of disease in our NHL group. We think that patients should receive a standard regimen if their performance status and any comorbid diseases are appropriate. However, the elderly patient group received a lower dose than the younger patient group. The biological and immunological characters of NHL in the elderly patient group are unclear, and since this group is not generally included in clinical studies, treatment-related difficulties persist.

\section{REFERENCES}

1. O. Bairey O, Benjamini D, Blickstein A, et al. Non-Hodgkin's lymphoma in patients 80 years of age or older. Ann Oncol 17: 928-934, 2006.

2. Monnereau A, Troussard X, Belot A, et al. Unbiased estimates of long-term net survival of hematological malignancy patients detailed by major subtypes in France. Int J Cancer 132: 23782387, 2013.

3. Link BK, Brooks J, Wright K, et al. Diffuse large B-cell lymphoma in the elderly: diffusion of treatment with rituximab and survival advances with and without anthracyclines. Leuk Lymphoma 52: 994-1002, 2011.

4. Bastion Y, Blay JY, Devine M, et al. Elderly patients with aggressive non-Hodgkin's lymphoma: disease presentation, response to treatment, and survivalea Groupe d'Etude des Lymphomes de l'Adulte study on 453 patients older than 69 years. J Clin Oncol 15: 2945-2953, 1997.

5. Maartense E, Kluin-Nelemans HC, le Cessie S, et al. Different age limits for elderly with indolent and aggressive non-Hodgkin lymphoma and the role of relative survival with increasing age. Analysis of a population-based non-Hodgkin Lymphoma registry. Cancer 89: 2667-2676, 2000.
6. Gomez H, Hidalgo M, Casanova L, et al. Risk factors for treatment-related death in elderly patients with aggressive nonHodgkin's lymphoma: result of a multivariate analysis. J Clin Oncol 16: 2065-2069, 1998.

7. Fried L, Bandeen RK, Kasper J, Guralnik J. Association of comorbidity with disability in older women: the women's health and aging study. J Clin Epidemiol 52: 22-37, 1999.

8. Extermann M. Measuring comorbidity in older cancer patients. Eur J Cancer Mar 36: 453-471, 2000.

9. Verbrugge LM, Lepkowski JM, Imanaka Y. Comorbidity and its impact on disability. Milbank Q 67: 450-484, 1989.

10. Guralnik JM, LaCroix AZ, Everett DF, Kovar MG. Aging in the eighties: the prevalence of comorbidity and its association with disability. Advance data from Vital and Health Statistics. 170: 26-28, 1989.

11. Mor V, Murphy J, Masterson Allen S, et al. Risk of functional decline among well elders. J Clin Epidemiol 42: 895-904, 1989.

12. Campbell AJ, Busby WJ, Robertson MC, et al. Disease, impairment, disability and social handicap: a community based study of people aged 70 years and over. Disabil Rehabil 16: 72-79, 1994.

13. Coiffier B, Lepage E, Briere J, Herbrecht R, Tilly H, Bouabdallah $\mathrm{R}$, et al. $\mathrm{CHOP}$ chemotherapy plus rituximab compared with $\mathrm{CHOP}$ alone in elderly patients with diffuse large-B-cell lymphoma. N Engl J Med 346: 235-242, 2002.

14. Pfreundschuh M, Schubert J, Ziepert M, et al. Six versus eight cycles of bi-weekly CHOP-14 with or without rituximab in elderly patients with aggressive CD20+ B-cell lymphomas: a randomised controlled trial (RICOVER-60). Lancet Oncol 9 : 105-116, 2008.

15. Otter R, Gerrits WBJ, Sandt MMVD, et al. Primary extranodal and nodal non-Hodgkin's lumphoma: a survey of a population-based registry. Eur J Cancer Clin Oncol 25: 1203-1210, 1989.

16. Carbone A, Volpe R, Gloghini A, et al. Non-Hodgkin's lymphoma in the elderly. Part I. Pathologic features at presentation. Cancer 66: 1991-1994, 1990.

17. D'Amore F, Brincker H, Christensen BE. for the Danish LYFOstudy group. Non-Hodgkin's lymphoma in the elderly. A study of 602 patients aged 70 or older from a Danish populationbased registry. Ann Oncol 3: 379-386, 1992.

18. Hoerni B, Sotto JJ, Eghbali H, et al. Non-Hodgkin's malignant lymphomas in patients older than 80: 70 cases. Cancer 61: 2057-2059, 1988.

19. Tirelli U, Carbone A, Monfardini S, Zagonel V. A 20-year experience on malignant lymphomas in patients aged 70 and older at a single institute. Crit Rev Oncol Hematol 37: 153158, 2001.

20. Grogan L, Corbally N, Dervan PA. Comparable prognostic factors and survival in elderly patients with aggressive nonHodgkin's lymphoma treated with standard-dose adriamycinbased regimen. Ann Oncol 5(S2): 47-51, 1994. 
21. Sonneveld $\mathrm{P}$, de Ridder $\mathrm{M}$, van der Lelie $\mathrm{H}$, et al. Comparison of doxorubicin and mitoxantrone in the treatment of elderly patients with advanced diffuse non-Hodgkin's lymphoma using CHOP versus CNOP chemotherapy. J Clin Oncol 13: 2530-2539, 1995.

22. Mainwaring PN, Cunningham D, Gregory W, et al. Mitoxantrone is superior to doxorubicin in a multiagent weekly regimen for patients older than 60 with high-grade lymphoma: results of a BNLI randomized trial of PAdriaCEBO versus PMitCEBO. Blood 97: 2991-2997, 2001.

23. Davis CC, Cohen JB, Shah KS, et al. Efficacy and tolerability of anthracycline-based therapy in elderly patients with diffuse large B-cell lymphoma. Clin Lymphoma Myeloma Leuk 15: 270-277, 2015.

\section{Correspondence}

Dr. Furkan SARICI

Hacettepe Üniversitesi Tip Fakültesi

Tibbi Onkoloji Anabilim Dali

Sihhiye, ANKARA / TURKEY

Tel: (+90-312) 3052941

email: saimfurkan@gmail.com 